\title{
PTGES2 Gene
}

National Cancer Institute

\section{Source}

National Cancer Institute. PT GES2 Gene. NCI Thesaurus. Code C105114.

This gene plays a role in prostaglandin biosynthesis. 